\title{
XXXIX. Experiments and observations on the manufacture of malleable iron directly from the ore
}

\section{Mushet Esq.}

To cite this article: D. Mushet Esq. (1802) XXXIX. Experiments and observations on the manufacture of malleable iron directly from the ore , Philosophical Magazine Series 1, 13:51, 234-239, DOI: $10.1080 / 14786440208676120$

To link to this article: http://dx.doi.org/10.1080/14786440208676120

Published online: 18 May 2009.

Submit your article to this journal $\pi$

Џll Article views: 2

Q View related articles $\sqsubset$ 
2I. To difcover in what ftate (with refpeet to electricity) the vapour was, I ufed the apparatus reprefented by the annexed Aketch, of which the upright A B is of glafs covered with fealing-wax, and all the reft, except the bottle of the electrometer, is of metal. In thirteen trials with cinders of pit-coal, the electrometer diverged $P$. feven times; four times it opened and clofed again before I could determine which ftate was produced, and twice it did not diverge at all.

22. In feven trials with marble, the electrometer diverged $\mathbf{N}$. three times; tliree times it lof all its divergence before I could determine in which ftate it diverged, and once it did not diverge at all.

In the two laft experiments, the electrometer retained its divergence fo fhort a time, that 1 was obliged to bold an excited tube in one hand, while I dropped the hot fubftance into the water with the other, to be ready in time to determine the fate produced by the vapour.

XXXIX. Experiments and Obfervations on the Manifakture of Malleable Iron directly from the Ore. By D. Musu ET, Ef $q$. of the Calder Iron litorks*.

I

$\mathrm{N}$ a former communication I took occafion to remark that a variety of proceffes had been followed out, endeavouring to form a good quality of bar iron with coak-pigs and pit-coal; but as thefe had been attended with little or no alteration of principle, the refults bad been nearly fimilar. In no cafe has an uniform quality of bar iron been produced, able to cope for all ufes with the fuperior marks of $S$ weden and Ruflia.

At this day, affifted by a variety of facts chemical and philofophical, we yet remain in comparative ignorance of what conftitutes the real difference in point of quality betwixt homemade iron and that imported from foreign markets. We acknowledge with pain and humiliation our dependence on other countries for our fteel-iron, and it is with regret that we fee every induftrious exertion made to obviate this depen dence foiled by the nature of our fuel, or the defective qua. lities of our ores.

Thofe who have voluntarily made an offer of their time and abilities for the fervice of their country, in promoting a thorongh knowledge of the principles of our manufactures, could not engage in a fubject fraught with more important

* Communicated by the Author. 
confequences. An acurate chemical analyfis of the various ftates and qualities of Britifh manufactured iron, accompanied by a fimilar development of the component parts of the foreign fabrics, would prove an interefting contraft, and could not fail ultimately of producing infinite advantage to that department of labour.

I thall not, at prefent, enter into an inveftigation of the probable reafons which conftitute this difference, but confine myfelf to a fuccinct account of feveral proceffes in which I have obtained malleable iron, often fuperior to the common run of Britifh manufacture. In contemplating thefe manipulations followed out in the large way, I uniformly found that, although fome fabrics poffeffed comparative excellence, yet that all were deficient in obtaining a quality of iron equal in appearance and fracture to the foreign.

In all thefe proceffes it was evident that if the contact of pit. coal, confidered as a more impure fuel than wood, was hurtful to the quality of the iron, then all our bar-iron would be fo injured, as all of it is manufactured either in contact with fuch fuel, or the flame of it, or both. The point therefore withed to be gained was the making of bariron without bringing the metal, while in fufion, in contact. either with the flame of pit-coal, or with the ignited coaks. My firt crude attempt was in 1794 with crucibles and roafted irontone. I conceived that by introducing juft as much charcoal of wood as would remove the oxygen of the ore, that malleable iron would be the refult. Experiment, in fome meafure, juttified this conjecture: but a want of uniformity in the refult proved the fallacy of this mode of operating. When the temperature was moderately raifed, I found the iron partially feparated, and, in a malleable ftate, entangled amongft the earths of the ore: but, when a higher degree of heat was brought on, the greateft part of the iron was found precipitated in the form of a button. The iron in this ftate was malleable: but fo exceffively red-fhort as to be incapable of drawing at any fhade of heat beyond faint red.

In varying thefe experiments, and ufing a greater proportion of charcoal than ufual, I was furprifed to find, that after a long and violent heat no part of the iron had entered into fufion. The pieces of iron-ftone were firmly connected together, poffeffed of the original acutenefs of angle and fracture. Their appearance and furface was dark and metallic, and, upon attempting to part them, I found them attached to each other by a fpecies of metallic fibre, which twifted repeatedly before breaking. This was a fpecies of welding I had never before witneffed. I found the whole mafs futficiently 
ciently metallic upon the furface to receive a confiderable degree of polith from a file. The interior of each piece, from the want of a fufficient dofe of heat, remained in a foft, eafily pulverifed form, perfectly magnetic, and burning with great rapidity when ftrewed in the flame.

The apparent advantages which feemed to refult from this chance difcovery were fufficient to induce me to perform, during the courfe of three or four years, feveral hundred experiments. In the profecution of this fubject, I foon abandoned the ufe of iron-ftones. It was found requifite to ufe them in a roafted ftate; and even afterwards, when heated in contact with charcoal for three or four days, it was with the greaten difficulty that the procefs of malleability could be made to penetrate to the centre without a general and premature fufion, which was always carefully to be avoided. When raw iron-ftone was ufed, it was difficult to prevent it from entering into fufion, and feparating its iron in the ftate of minute globules of crude iron. Having thus fatisfied myfelf of the precarious refults obtained in this procefs by the ufe of iron-ftones, I had recourfe to Cumberland ore, as a fit fubltitute, and my expectations in it were not difappointed.

I thall fimply ftate the methods which I ultimately followed to produce bar-iron in this procefs with the ufe of pit-coal and charcoal of wood. Having prepared a fmall furnace with an oblong cavity, furrounded with a fufficient number of holes to admit the heat all round, I introduced 50 to $60 \mathrm{lbs}$. of Cumberland iron ore reduced to pieces of nearly 3 ounces weight each. This was mixed with a fufficient quantity of clean duft produced in the charring of cnal. The ore was furrounded by a layer nearly $2:$ inches thick, and this laft of all was covered with a layer of moift fand 2 to 3 inches thick. The fire was maintained at a temperature of nearly $100^{\circ}$ of Wedgewood for $3^{6}$ to 48 hours, according to circumftances. It was then allowed to cool gradually. Upon examination, the pieces of ore were frequently found attached to each other fo firmly as to require confiderable force to part them. They filed, and were, when the cementation was continued long enough, malleable throughout. The ore, thus prepared, was piled up in a flat broad fhallow crucible with a loofe top, and placed in a furnace heated with the flame of pitcoal. A welding heat was brought on the whole mafs, which was then carried to the hammer: the firft blow deftroyed the crucible, and the ore was fhingled into a bloom at the firft heat.

In this way excellent iron was produced. Its fracture was light 
light blue, fibrous, and tearing confiderably in groups. It poffeffed, however, a flight degree of red-fhortnefs when very highly heated. It formed with equal facility horfethoes and nails of the moft delicate ftructure. The produce of the raw ore never exceeded 47 per cent., and commonly was from 43 to 45 . Iron of a more pure fracture was obtained by piling the ore upon a flat cake of fire-clay or fand-ftone. As the welding heat penetrated the mafs, part of the earth and unmetallized particles of iron were reduced into fufion, and run off into the furnace. The produce, however, in iron was reduced as low as 37 per cent. This reduction of metal, no doubt, arofe from the greater furface expofed in this way than when the balling pot was ufed.

To obviate this, and, at the fame time, infure an equal quality of iron, the piles were heated in the fame furnace with the gas of coaks, and the flue of the furnace nearly thut up ; 'fo that the circulation of air was much fmaller, and the heat, though equally great, yet more attenuated. This produced a better quality of iron than any of the former ways, but at a greater expenfe of fuel.

However fuitable this iron was for the common ufes of the fmithy, it was found to form but a very indifferent quality of fteel by cementation. The whole of it became in fome degree laminated, and incapable of ftanding great fatigue; and the red-fhortnefs, which before faintly marked the bar iron, was now confiderably increafed when in the ftate of fteel.

In varying this procefs of making bar iron, quantities of the prepared ore were thrown upon the top of a fmall finery fire, charged with foft coal coak, and funk to the botton. The metallic mafs was found connected, and fo much purified as to afford iron of a clear fracture, but the produce was diminifhed to 28 and 30 per cent. from raw ore.

The fame ore, however, funk in a fmall fire of wood charcoal, yielded a very fuperior quality of the metal to any of the former. In point of quality and fracture, it was deemed no way inferior to many of the beft Swedinh marks. Still, however, it muft not be denied, that this iron formed comparatively but an inferior quality of fteel. In this ftate I left this procefs for making bar iron, and have not yet found time nor fufficient opportunity to refume it. Of late years I underftand a procefs, fomew hat fimilar, has buen eftablifhed near Whitehaven, in the neighbourhood of the Cumberland iron-mines, but abandoned, not becaufe the quality of iron was inferior, but I believe from a want of œconomy in the proct 1 itfelf.

A thoufand unforefeen difficulties occur in ftriking out a 
new line of manufacture, before a good quality of product is obtained. Thefe are feldom diminifhed, but often increafed; in transferring it from the fcale of experiment to that of manufacture.

In the prefent procefs followed out at the bar-iron forges in this country, the greatef drawback upon the profits and correctnefs of the bufinefs is the immenfe lofs of metal. This is called wafte, and it is generally believed that the more the wafte the better the quality of the refulting iron. This circumftance I conceive is owing to the following factsthe combuftibility of the metal, the high temperature requifite, and the tedious length of the procefs. The puddling procels invented by Cortes avowed a degree of fimplicity; which promifed to leffen the wafte by diminifhing the variety of operations, and the length of the expofure. Experience however has proved, that, in general, what was gained in weight was more than loft by the inferior quality of the iron produced.

With a view to produce a quality of iron-from coak pig equal or fuperior to what is obtained in the beft proceffes now in ufe, it occurred to me that an operation which would unite the properties of the finery fire and of the puddling furnace would be productive of a good quality of iron, and with little comparative lofs. With this view a fmall furnace was contrived, fomewhat fimilar in thape to an iron-founder's air furnace. The depth of the grates below what is called the bridge of the furnace was more in proportion. A thallow cavity was formed in the middle of the furnace with fand, about two inches deep, fifteen inches long, and eight broad. The furnace was heated to a bright white heat with raw pit-coal : a fmall door was then opened, and nearly $84 \mathrm{lbs}$ of fragments of white crude iron introduced. The grates of the furnace were then charged with coaks, and a femifuring heat brought on, and continued for ten hours after. During this operation the metal continued to boil, and difcharge a blue vapour, frequently accompanied with hiffing explofions. At laft, when the metal exhibited no further figns of ebullition, nor of fufion, the fire was allowed to die away. When cold, I found the whole, without ftirring or agitation, refolved into a mafs of malleable iron, which, even in this ftate, was broken with great difficulty: The lunp, or plate, was divided into three pieces, one of which was drawn into a ftout bar, and weighed $18 \mathrm{lbs}$. The quality of this iron was excellent for every purpofe, fteel-making excepted. In this procefs it disjoined, and formed laminæ; which rentered it unfit for any fteel purpofe. This experiment was fre- 
quently repeated with fimilar refults : but, from feveral circumftances not here neceffary to be mentioned, I never afcertained the exact lofs fuftained in the operations. I am confident, however, that it would not amount to more than half what is experienced in the common proceffes.

I offer this light Ketch, as I did the former, merely as an outline of an operation, the perfection of which might be attended with great advantages, but which would previoufy require a confiderable portion of time, and many experiments, to eftablin.

\section{An Effay on Longerity. By Sir Joh N Sinclain, Bart.}

[Continued from p. 172.]

\section{APPENDIX.}

No. 1.

T

HE preceding obfervations are only intended as a bafis, for the purpofe of obtaining the additional facts and obfervations which are neceffary to elucidate fo important an inquiry. It is particularly requefted, therefore, that the following queftions may be anfwered with as much minutenefs and accuracy as circumftances will admit of.

Queftions for the confideration of thofe intelligent perfons by whom this Paper may be perufed:-

1. What is the effect of the climate in which you refide, on the health and longevity of the human race?

2. What form is reckoned moft conducive to health and longevity?

3. ' $s$ it found, that being defcended from young and from healthy parents, is effential for good health and old age?

4. Is it found, that health and old age depend much on the difpofition or temper of the individual?

5. Is there any perceptible difference in confequence of fituation of life?

6. What profeffions are reckoned favourable to longevity or otherwife?

7. Is exercife or moderate labour found neceffary for preferving health and long life? ftate ?

8. Have the long-lived in general been in the marriage-

9. Have the greateft proportion of the long-lived confifted of males or females? 